\title{
PACIENTŲ SVEIKATOS PRIEŽIŪROS IR SOCIALINIŲ VEIKSNIŲ SĄSAJOS BEI JŲ VALDYMO YPATUMAI
}

\author{
Jurgita Platakytė \\ Klaipédos universitetine ligoniné
}

Raktažodžiai: sveikata, sveikatos priežiūra, pacientas, socialiniai veiksniai, valdymas.

\section{Santrauka}

Straipsnis supažindina su ligoninèse gydomų pacientų sveikatos priežiūra ir socialiniais veiksniais, jų sąsajomis bei sveikatos priežiūros ir socialinių veiksnių sąsajų valdymu. Siekiant nustatyti sveikatos priežiūros ir socialinių veiksnių sąsajas bei sveikatos priežiūros ir socialinių veiksnių sąsajų valdymą, atliktas kiekybinis tyrimas, naudojant originalų autorès sudarytą klausimyną. Tyrimo tikslas - išanalizuoti ligoninès pacientų sveikatos priežiūros ir socialinių veiksnių sąsajas bei jų valdymo ypatumus. Atlikto empirinio tyrimo rezultatai parodè, kad socialinių veiksnių grupés: socialinès aplinkos veiksniai, darbo ịvykiai ir pokyčiai, asmeniniai įvykiai ir individualių charakteristikų pokyčiai, gyvenimo ìvykiai bei pokyčiai ir kt. veikia pacientų sveikatą. Nedarbas, skurdas, materialiniai (finansiniai) sunkumai bei skolos, itemptas darbas, bloga darbo aplinka ir kenksmingos darbo sąlygos, artimujų ligos ir mirtys - veiksniai, turintys didelès ịtakos sveikatos priežiūrai. Medicinos darbuotojams teikiant savo pasiūlymus dèl inovatyvių gydymo priemonių, organizacinių metodų taikymo bei teikiamų paslaugų kokybės gerinimo, galima prisidèti prie sveikatos priežiūros valdymo.

\section{Ivadas}

Pacientų, kurie dèl ịvairių sveikatos sutrikimų naudojasi sveikatos priežiūros įstaigų teikiamomis paslaugomis, skaičius ligoninèse didejja, todèl nuolat kintančiame pasaulyje sveikatos priežiūra, jos kokybe, valdymas ir pritaikymas yra vienas iš svarbiausių sveikatos priežiūros prioritetų [9]. Šiame kontekste svarbūs ne vien ịstaigu infrastruktūros rodikliai, tokie kaip personalas, iranga, medikamentai [15], bet ir pacientų nuomonè, vertinimai, medikų bei pacientų tarpusavio komunikacija $[6,21,22]$. Medikų nuomonè sveikatos priežiūros kokybès klausimais yra neatsiejama, tačiau ji ver- tinama kaip antrinè, t. y. per pacientų nuomonès prizmę [8]. Remiantis Lietuvos Respublikos pacientų teisių ir žalos sveikatai atlyginimo įstatymu (1996; galiojanti suvestinè redakcija 2021-07-01) kokybiška sveikatos priežiūra apibrèžiama kaip prieinamos, saugios, veiksmingos sveikatos stiprinimo, ligų prevencijos, diagnostikos, ligonių gydymo ir slaugos paslaugos, kurias tinkamam pacientui, tinkamu laiku, tinkamoje vietoje suteikia tinkamas sveikatos priežiūros specialistas ar sveikatos priežiūros specialistų komanda pagal šiuolaikinio medicinos ir slaugos mokslo lygị ir gerą patirtį, atsižvelgdami i paslaugos teikèjo galimybes ir paciento poreikius bei lūkesčius, juos tenkindami ar viršydami [16].

Kai kurie autoriai sveikatos sampratoje akcentuoja socialinę gerovę, kuri reiškia ne tik ligų, fizinių trūkumų nebuvimą, tačiau ir asmens gebejjimą dalyvauti savo sveikatos priežiūros procese $[7,10]$, kiti sveikatą, sveikatos priežiūrą ìvardija ne tik kaip biomedicinos, bet ir socialinių mokslų srities pažinimo objektą [2,5,13]. A. Jurgelènas ir kt. (2007) tvirtina, kad PSO strategija „Sveikata visiems“ daugiausia dèmesio skiria sveikatos būklei, kuri yra daugiau kokybinis nei kiekybinis sveikatos vertinimo parametras, o ne ligai, kaip tai buvo daroma anksčiau. Norint adekvačiai suvokti kokybinį sveikatos vertinimo parametrą, sveikatos sąvoką reikia sieti su integralia individualios charakteristikos, gyvenimo būdo, didžiujų aplinkos (fizinių, kultūrinių, politinių ir kt.) ir socialinių veiksnių sąveika $[10,11]$.

Socialiniai veiksniai lemia daugiau negu pusę ligų. Jie apima sąlygas, kuriomis žmonės gimsta, auga, dirba, gyvena ir sensta, jègas ir sistemas, formuojančias kasdienio gyvenimo sąlygas (šalies ekonominè politika, socialinès normos, socialinè politika, kt.). Skiriami socialiniai veiksniai, galintys tiek teigiamai, tiek neigiamai paveikti sveikatą: pajamos ir socialine apsauga, švietimas, nedarbas ir darbo nesaugumas, darbo ir gyvenimo sąlygos, maisto nesaugumas, būstas, pagrindiniai patogumai ir aplinka, ankstyvosios vaikystès raida, socialinè ịtrauktis ir nediskriminavimas, struktūrinis konfliktas [29].

V. Janušonis (2008) skiria keturias pagrindines sociali- 
nių veiksnių (stresorių) grupes: socialinès aplinkos išoriniai veiksniai, gyvenimo įvykiai ir pokyčiai, darbo ịvykiai ir pokyčiai bei asmeniniai ịvykiai ir individualių charakteristiku pokyčiai. Pastarieji sukelia socialinị (gyvenimo) stresą, kuris išprovokuoja vidinį stresą ir veikia paciento asmeninę sveikatą labiau neigiamai, negu teigiamai [10]. Vis svarbesnis tampa valdymo procesas, kuris padeda prisitaikyti prie aplinkos pokyčių ir pasiekti užsibrèžtų tikslų bei poreikių, lūkesčių tenkinimo.

Labai didelę itaką žmogaus sveikatai turi amžius, profesija, atliekamas darbas, šeima, kultūra, tradicijos bei elgesio stereotipai, finansinè padètis, socialiniai ryšiai visuomeneje [12].

Sveikatos priežiūros sistema pati savaime yra socialinis sveikatą lemiantis veiksnys, kuris veikia ir yra veikiamas kitų socialinių veiksnių. Sveikatos priežiūros ir socialinių veiksnių tarpusavio priklausomybè - problema, veikianti sveikatos priežiūros kokybę, todèl svarbu rasti pacientų sveikatos priežiūros ir socialinių veiksnių sąsajas bei jų valdymo gerinimo prielaidas ligoninèse.

Tyrimo tikslas. Išanalizuoti ligoninès pacientų sveikatos priežiūros ir socialinių veiksnių sąsajas bei jų valdymo ypatumus.

\section{Tyrimo medžiaga ir metodai}

Kiekybinis tyrimas atliktas iki COVID-19 pandemijos trijose Lietuvos miestų ligoninèse, teikiančiose stacionarines ir ambulatorines-konsultacines III lygio paslaugas. Apklausti vidaus ligų, chirurgijos, onkologijos bei akušerijos-ginekologijos profilio pacientai ir ịstaigose dirbantys medicinos darbuotojai (gydytojai, slaugytojai ir jiems prilygintas personalas). Respondentams klausimynas sudarytas darbo autorès, remiantis panašių atliktų mokslinių tyrimų duomenimis ir teoriniais kriterijais. Taikyta neatsitiktine patogioji respondentu atranka. Tyrimui naudoti 428 klausimynai. Grąžinimo rodiklis $-95,8$ procento. Apklausti 220 pacientu ir 208 medicinos darbuotojai.

Pacientų klausimynas sudarytas iš 18 uždaro tipo klausimų, medicinos darbuotojų - 18 uždaro ir 2 pusiau uždaro tipo klausimų. Klausimynų patikimumui ịvertinti naudotas Cronbach alpha koeficientas, kuriuo, remiantis paskirų klausimynus sudarančių klausimų koreliacija, ịvertinta, ar visi skalès klausimai pakankamai atskleidžia tiriamajị dydị ir igalina patikslinti reikiamų klausimų skaičių skalèje [23]. Pacientų ir medicinos darbuotojų klausimynų blokų koeficientai yra $0,668-0,820$, tai parodo, kad naudoti klausimynai pakankamai patikimi.

Pagrindinès tyrimo imties pacientų charakteristikos pateiktos 1 lentelèje.

Didžioji dalis respondentų pacientų apklausos metu gy- dèsi vidaus ligų profilio skyriuose (34,1 proc.). Kiti pasiskirste tolygiai: chirurgijos profilio 23,6 proc., onkologijos - 18,2 proc., akušerijos-ginekologijos - 24,1 procento.

Pagrindinès tyrimo imties (medicinos darbuotojų ir kito personalo) charakteristikos pagal užimamas pareigas pateikiamos 2 lentelëje.

Tyrimo duomenys statistiškai apdoroti naudojant kompiuterinès programos SPSS for Windows 21 versiją (Statistical Package for Social Sciences) ir kompiuterinę programą Microsoft Office Excel 2013. Dviejų nepriklausomų grupių požymių vidurkių lyginimui naudotas Student $t$ kriterijus, kai požymiai tenkino normalumo prielaidas. Apskaičiuotas Chi kvadrato kriterijus $\left(\chi^{2}\right)$, laisvès laipsnių skaičius (lls), statistinis reikšmingumas ( $\mathrm{p}$ reikšmè).

1 lentelè. Pagrindinès tyrimo imties (pacientų) charakteristikos.

\begin{tabular}{|c|c|c|}
\hline \multirow{2}{*}{ Charakteristikos } & \multicolumn{2}{|c|}{ Iš viso } \\
\hline & $\mathrm{N}=220$ & 100 proc. \\
\hline \multicolumn{3}{|c|}{ Lytis } \\
\hline Moterys & 157 & 71,4 \\
\hline Vyrai & 63 & 28,6 \\
\hline \multicolumn{3}{|c|}{ Amžius (metais) } \\
\hline$<36 \mathrm{~m}$ & 44 & 20,0 \\
\hline $36-55 \mathrm{~m}$. & 92 & 41,8 \\
\hline $56-75 \mathrm{~m}$. & 74 & 33,7 \\
\hline$\geq 76 \mathrm{~m}$ & 10 & 4,5 \\
\hline \multicolumn{3}{|c|}{ Išsilavinimas } \\
\hline Nebaigtas vidurinis & 29 & 13,2 \\
\hline Vidurinis & 42 & 19,1 \\
\hline Spec. vidurinis & 54 & 24,5 \\
\hline $\begin{array}{l}\text { Aukštesnysis (aukštasis) } \\
\text { neuniversitetinis }\end{array}$ & 57 & 25,9 \\
\hline Aukštasis universitetinis & 38 & 17,3 \\
\hline \multicolumn{3}{|c|}{ Gyvenamoji vieta } \\
\hline Miestas & 148 & 67,3 \\
\hline Rajonas & 72 & 32,7 \\
\hline \multicolumn{3}{|c|}{ Šeiminè padètis } \\
\hline Vienišas (-a) & 17 & 7,7 \\
\hline Vedęs (ištekèjusi) & 141 & 64,1 \\
\hline Išsiskyręs (-usi) & 20 & 9,1 \\
\hline Našlys (-è) & 22 & 10,0 \\
\hline Turi gyvenimo draugą (-ę) & 20 & 9,1 \\
\hline \multicolumn{3}{|c|}{ Priklausymas socialinei grupei } \\
\hline Dirbantis $(-i)$ & 125 & 56,8 \\
\hline Bedarbis (-è) & 7 & 3,2 \\
\hline Pensininkas (-è) & 46 & 20,9 \\
\hline Moksleivis (studentas) (-è) & 6 & 2,7 \\
\hline Neigalusis (-i) & 31 & 14,1 \\
\hline Namų šeimininkè & 5 & 2,3 \\
\hline
\end{tabular}


2 lentelè. Pagrindinès tyrimo imties (medicinos darbuotojų) charakteristikos pagal užimamas pareigas.

Santrumpos: $\chi^{2}$ - Chi kvadrato kriterijus; lls - laisvés laipsniu skaičius; $p$-statistinis reikšmingumas

\begin{tabular}{|l|c|c|c|c|c|c|}
\hline \multirow{3}{*}{ Charakteristikos } & \multicolumn{5}{|c|}{ Užimamos pareigos } \\
\cline { 2 - 7 } & \multicolumn{3}{|c|}{ gydytojai } & \multicolumn{2}{c|}{ slaugytojai } & \multicolumn{1}{c|}{$\begin{array}{c}\text { kitas perso- } \\
\text { nalas }\end{array}$} \\
\cline { 2 - 7 } & $\mathrm{N}$ & proc. & $\mathrm{N}$ & proc. & $\mathrm{N}$ & proc. \\
\hline Iš viso & 40 & 19,2 & 139 & 66,8 & 29 & 14,0 \\
\hline
\end{tabular}

\section{Amžius (metais)}

\begin{tabular}{|l|c|c|c|c|c|c|}
\hline$<30 \mathrm{~m}$. & 9 & 22,5 & 9 & 6,5 & 11 & 37,9 \\
\hline $30-49 \mathrm{~m}$. & 17 & 42,5 & 89 & 64,0 & 10 & 34,5 \\
\hline $50-79 \mathrm{~m}$. & 14 & 35,0 & 41 & 29,5 & 8 & 27,6 \\
\hline
\end{tabular}

$\left(\chi^{2}=150,9\right.$, lls $\left.=94, p<0,001\right)$

Lytis

\begin{tabular}{|l|c|c|c|c|c|c|}
\hline Moterys & 10 & 25,0 & 139 & 100,0 & 13 & 44,8 \\
\hline Vyrai & 30 & 75,0 & 0 & 0,0 & 16 & 55,2 \\
\hline
\end{tabular}

$\left(\chi^{2}=122,8\right.$, lls $\left.=2, p<0,001\right)$

Darbo profilis

\begin{tabular}{|c|c|c|c|c|c|c|}
\hline Vidaus ligų profilis & 3 & 7,5 & 45 & 32,4 & 16 & 55,2 \\
\hline Chirurgijos profilis & 17 & 42,5 & 46 & 33,1 & 5 & 17,2 \\
\hline Onkologijos profilis & 7 & 17,5 & 22 & 15,8 & 2 & 6,9 \\
\hline $\begin{array}{l}\text { Akušerijos-gineko- } \\
\text { logijos profilis }\end{array}$ & 13 & 32,5 & 26 & 18,7 & 6 & 20,7 \\
\hline
\end{tabular}

Duomenų skirtumas laikytas statistiškai reikšmingu, kai p reikšmė yra mažesnè negu $0,05(* \mathrm{p}<0,05)$, arba statistinė išvada yra labai reikšminga, jei $\mathrm{p} \leq 0,01(* * \mathrm{p}<0,01)$, arba statistinè išvada yra itin reikšminga, jei $\mathrm{p} \leq 0,001(* * * \mathrm{p}<0,001)$.

\section{Rezultatai ir jų aptarimas}

Sveikatos priežiūros paslaugų kokybės neįmanoma vertinti ir gerinti nesant pacientų ir medicinos darbuotojų nuomonès [19].

Ligoninès ar kito sveikatos priežiūros subjekto pasirinkimui pacientai mažiau remiasi objektyvia informacija, daugiau įvaizdžiu bei įspūdžiu $[1,25,26]$. Pasak A. Mikaliūkštienès ir kt. (2018), norint išlaikyti esamus pacientus bei pritraukti naujus, svarbu patenkinti esamujų poreikius [17]. Vykdant tyrimą, siekta išsiaiškinti pacientų kreipimosi dažnị ị tą pačią sveikatos priežiūros ịstaigą, bei asmenis(-ị) ar instituciją, atsakingus(-ą) už paciento sveikatą gydymosi stacionare laikotarpiu. Nustatyta, kad daugiau nei pusės apklaustų pacientų ir medicinos darbuotojų nuomonè sutampa dèl kreipimosi dažnio ị tą pačią sveikatos priežiūros ịstaigą bei medicinos darbuotojų atsakomybę už pacientų sveikatos priežiūrą. Statistiškai patikimo skirtumo tarp grupių nebuvo.

Siekiant suteikti efektyvias bei kokybiškas medicinos paslaugas, neišvengiamai ị pacientų gydymo procesą patenka jų socialinis kontaktas su aplinka, kitais asmenimis, visuomene [5].

Atliekant tyrimą, siekta atskleisti subjektu grupes, skatinančias socialinių veiksnių įtaką sveikatos priežiūrai. Apklaustų pacientų nuomonè statistiškai reiksmingai $(\mathrm{p}<0,05)$ skyrèsi. Daugiau nei pusé apklaustų pacientų nurodè, jog socialiniai tinklai internete $(50,5$ proc.) ir draugai bei artimieji (74,1 proc.) daro įtaką socialiniams veiksniams, veikiantiems sveikatos priežiūrą. 43,6 proc. pacientų nurodo, jog pacientų draugijos skatina socialinių veiksnių įtaką sveikatos priežiūrai, kiti - savitarpio paramos grupès ( 44,1 proc.), teritorinės bendruomenès ( 31,8 proc.) ir religinès bendruomenès $(25,9$ proc.). Medicinos darbuotojų nuomonè statistiškai patikimai skyrèsi $(\mathrm{p}<0,001)$. Jie akcentavo, kad pacientų draugijos $(68,8$ proc.), socialiniai tinklai internete ( 66,8 proc.), savitarpio paramos grupès $(69,2$ proc.), draugai bei artimieji

3 lentelè. Socialiniai aplinkos veiksniai, jų svarba sveikatai ir sveikatos priežiūrai.

\begin{tabular}{|c|c|c|c|c|c|c|c|c|c|c|c|c|}
\hline \multirow{3}{*}{$\begin{array}{l}\text { Pasirinkimo vari- } \\
\text { antai }\end{array}$} & \multirow{3}{*}{ Respondentai } & \multicolumn{10}{|c|}{ Vertinimas } & \multirow{4}{*}{ 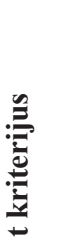 } \\
\hline & & \multicolumn{2}{|c|}{ labai svarbūs } & \multicolumn{2}{|c|}{ svarbūs } & \multicolumn{2}{|c|}{$\begin{array}{l}\text { vidutinès svar- } \\
\text { bos }\end{array}$} & \multicolumn{2}{|c|}{ nelabai svarbūs } & \multicolumn{2}{|c|}{ nesvarbūs } & \\
\hline & & $\mathrm{N}$ & proc. & $\mathrm{N}$ & proc. & $\mathrm{N}$ & proc. & $\mathrm{N}$ & proc. & $\mathrm{N}$ & proc. & \\
\hline \multicolumn{12}{|c|}{ Socialinės aplinkos veiksniai: } & \\
\hline \multirow[b]{2}{*}{ Nedarbas } & Pacientai & 127 & $57,7 * * *$ & 73 & 33,2 & 14 & 6,4 & 2 & 0,9 & 4 & 1,8 & \multirow[b]{2}{*}{0,81} \\
\hline & $\begin{array}{l}\text { Medicinos darbuo- } \\
\text { tojai }\end{array}$ & 132 & $63,5 * * *$ & 57 & 27,4 & 16 & 7,7 & 1 & 0,5 & 2 & 1,0 & \\
\hline \multirow{2}{*}{$\begin{array}{l}\text { Skurdas (nepakanka- } \\
\text { mos pajamos) }\end{array}$} & Pacientai & 154 & $70,0 * * *$ & 52 & 23,6 & 11 & 5,0 & 2 & 0,9 & 1 & 0,5 & \multirow[b]{2}{*}{0,67} \\
\hline & $\begin{array}{l}\text { Medicinos darbuo- } \\
\text { tojai }\end{array}$ & 140 & $67,3 * * *$ & 58 & 27,9 & 8 & 3,8 & 0 & 0,0 & 2 & 1,0 & \\
\hline \multirow{2}{*}{$\begin{array}{l}\text { Profesinè diskrimi- } \\
\text { nacija }\end{array}$} & Pacientai & 79 & $35,9 * * *$ & 60 & 27,3 & 42 & 19,1 & 25 & 11,4 & 14 & 6,4 & \multirow[b]{2}{*}{1,23} \\
\hline & $\begin{array}{l}\text { Medicinos darbuo- } \\
\text { tojai }\end{array}$ & 66 & 31,7 & 86 & $41,3 * * *$ & 35 & 16,8 & 14 & 6,7 & 7 & 3,4 & \\
\hline
\end{tabular}


(78,4 proc.) yra tos subjektų grupės, labiausiai skatinančios socialinių veiksnių ịtaką sveikatos priežiūrai.

Apklaustu pacientų nuomone, jiems pasirenkant sveikatos priežiūros įstaigą, didžiausią įtaką turèjo draugai bei kiti artimieji (72,3 proc.). Medicinos darbuotojai, išsakydami savo nuomonę, pritare pacientų nuomonei dèl draugų ir kitų artimų asmenų įtakos, pasirenkant sveikatos priežiūros įstaigą (90,4 proc.), tačiau dar nurodè, jog pasirinkimui įtakos turi pacientų draugijos (67,3 proc.) ir socialiniai tinklai $(75,0$ proc.). Ši nuomonè tarp medicinos darbuotojų statistiškai reikšmingai skyrėsi $(\mathrm{p}<0,001)$.

Nustatyti statistiškai reikšmingi skirtumai, vertinant veiksnius, galinčius neigiamai paveikti sveikatos priežiūrą $(\mathrm{p}<0,05)$. Daugiau nei pusė apklaustų pacientų nurodė, jog visi išvardinti veiksniai gali neigiamai paveikti sveikatos priežiūrą: pacientų žinios apie sveikatą ir sveikatos priežiūrą, pacientų žinios apie kitas ligas, pacientų žinios apie savo ligą, pacientų žinios apie savipagalbą, nuolatinis kontaktas su šeimos gydytoju, paciento motyvacija palaikyti sveikatą. Sveikatos specialistai, kaip ir pacientai, sutiko su nuomone, jog pacientų žinios apie sveikatą, sveikatos priežiūrą, apie savo ir kitas ligas, savipagalba bei kontaktas su šeimos gydytoju ir motyvacija daro poveikị sveikatos priežiūrai.

Vykdyto tyrimo metu buvo siekta išsiaiškinti, kokie socialiniai veiksniai yra svarbūs žmonių sveikatai ir jų sveikatos priežiūrai. Respondentams pateikti socialiniai veiksniai

4 lentelè. Gyvenimo ịvykiai bei pokyčiai, jų svarba sveikatai ir sveikatos priežiūrai.

\begin{tabular}{|c|c|c|c|c|c|c|c|c|c|c|c|c|}
\hline \multirow{3}{*}{$\begin{array}{l}\text { Pasirinkimo } \\
\text { variantai }\end{array}$} & \multirow{3}{*}{ Respondentai } & \multicolumn{10}{|c|}{ Vertinimas } & \multirow{3}{*}{ 象 } \\
\hline & & \multicolumn{2}{|c|}{ labai svarbūs } & \multicolumn{2}{|c|}{ svarbūs } & \multicolumn{2}{|c|}{$\begin{array}{l}\text { vidutinès svar- } \\
\text { bos }\end{array}$} & \multicolumn{2}{|c|}{ nelabai svarbūs } & \multicolumn{2}{|c|}{ nesvarbūs } & \\
\hline & & $\mathrm{N}$ & proc. & $\mathrm{N}$ & proc. & $\mathrm{N}$ & proc. & $\mathrm{N}$ & proc. & $\mathrm{N}$ & proc. & \\
\hline \multirow{2}{*}{$\begin{array}{l}\text { Artimujų mirtys } \\
\text { ir ligos }\end{array}$} & Pacientai & 128 & $58,2 * * *$ & 73 & 33,2 & 16 & 7,3 & 3 & 1,4 & 0 & 0,0 & \multirow[b]{2}{*}{0,69} \\
\hline & $\begin{array}{l}\text { Medicinos dar- } \\
\text { buotojai }\end{array}$ & 105 & 31,7 & 74 & $35,6 * *$ & 24 & 11,5 & 2 & 1,0 & 3 & 1,4 & \\
\hline \multirow{2}{*}{$\begin{array}{l}\text { Skyrybos, } \\
\text { vedybos }\end{array}$} & Pacientai & 99 & $45,0 *$ & 75 & 34,1 & 34 & 15,5 & 9 & 4,1 & 3 & 1,4 & \multirow[b]{2}{*}{0,93} \\
\hline & $\begin{array}{l}\text { Medicinos dar- } \\
\text { buotojai }\end{array}$ & 79 & $38,0 * *$ & 73 & 35,1 & 40 & 19,2 & 12 & 5,8 & 4 & 1,9 & \\
\hline \multirow{2}{*}{$\begin{array}{l}\text { Ilgalaikiai } \\
\text { sutuoktinių } \\
\text { išsiskyrimai }\end{array}$} & Pacientai & 68 & 30,9 & 73 & $33,2 *$ & 48 & 21,8 & 27 & 12,3 & 4 & 1,8 & \multirow[b]{2}{*}{1,07} \\
\hline & $\begin{array}{l}\text { Medicinos dar- } \\
\text { buotojai }\end{array}$ & 52 & 25,0 & 70 & 33,7 & 58 & 27,9 & 21 & 10,1 & 7 & 3,4 & \\
\hline \multirow{2}{*}{$\begin{array}{l}\text { Nesutarimai } \\
\text { šeimoje }\end{array}$} & Pacientai & 87 & $39,5 * * *$ & 79 & 35,9 & 40 & 18,2 & 11 & 5,0 & 3 & 1,4 & \multirow[b]{2}{*}{0,95} \\
\hline & $\begin{array}{l}\text { Medicinos dar- } \\
\text { buotojai }\end{array}$ & 71 & 34,1 & 81 & $38,9 * * *$ & 42 & 20,2 & 9 & 4,3 & 5 & 2,4 & \\
\hline \multirow{2}{*}{$\begin{array}{l}\text { Materialiniai } \\
\text { (finansiniai) } \\
\text { sunkumai, } \\
\text { skolos }\end{array}$} & Pacientai & 115 & $52,3 * * *$ & 78 & 35,5 & 22 & 10,0 & 2 & 0,9 & 3 & 1,4 & \multirow[b]{2}{*}{0,81} \\
\hline & $\begin{array}{l}\text { Medicinos dar- } \\
\text { buotojai }\end{array}$ & 97 & $46,6 * * *$ & 79 & 38,0 & 26 & 12,5 & 2 & 1,0 & 4 & 1,9 & \\
\hline \multirow{2}{*}{$\begin{array}{l}\text { Gyvenamosios } \\
\text { vietos pakeiti- } \\
\text { mas }\end{array}$} & Pacientai & 50 & 22,7 & 57 & 25,9 & 49 & 22,3 & 49 & 22,3 & 15 & 6,8 & \multirow[b]{2}{*}{1,24} \\
\hline & $\begin{array}{l}\text { Medicinos dar- } \\
\text { buotojai }\end{array}$ & 29 & 13,9 & 67 & $32,2 * * *$ & 67 & 32,2 & 31 & 14,9 & 14 & 6,7 & \\
\hline \multirow{2}{*}{$\begin{array}{l}\text { Nauji šeimos } \\
\text { nariai }\end{array}$} & Pacientai & 56 & 25,5 & 54 & 24,5 & 40 & 18,2 & 50 & 22,7 & 20 & 9,1 & \multirow[b]{2}{*}{1,32} \\
\hline & $\begin{array}{l}\text { Medicinos dar- } \\
\text { buotojai }\end{array}$ & 29 & 13,9 & 71 & $34,1 * * *$ & 62 & 29,8 & 32 & 15,4 & 14 & 6,7 & \\
\hline \multirow{2}{*}{$\begin{array}{l}\text { Nesantuokiniai } \\
\text { ryšiai }\end{array}$} & Pacientai & 51 & 23,2 & 50 & 22,7 & 35 & 15,9 & 48 & 21,8 & 36 & 16,4 & \multirow[b]{2}{*}{1,42} \\
\hline & $\begin{array}{l}\text { Medicinos dar- } \\
\text { buotojai }\end{array}$ & 29 & 13,9 & 53 & 25,5 & 55 & 26,4 & 43 & 20,7 & 28 & 13,5 & \\
\hline \multirow{2}{*}{$\begin{array}{l}\text { Socialinè mi- } \\
\text { gracija }\end{array}$} & Pacientai & 60 & 27,3 & 51 & 23,2 & 43 & 19,5 & 45 & 20,5 & 21 & 9,5 & \multirow[b]{2}{*}{1,33} \\
\hline & $\begin{array}{l}\text { Medicinos dar- } \\
\text { buotojai }\end{array}$ & 35 & 16,8 & 53 & 25,5 & 64 & $30,8 * * *$ & 37 & 17,8 & 19 & 9,1 & \\
\hline \multirow{2}{*}{$\begin{array}{l}\text { Socialinè izo- } \\
\text { liacija }\end{array}$} & \begin{tabular}{|l|} 
Pacientai \\
\end{tabular} & 59 & 26,8 & 68 & 30,9 & 42 & 19,1 & 34 & 15,5 & 17 & 7,7 & \multirow[b]{2}{*}{1,25} \\
\hline & $\begin{array}{l}\text { Medicinos dar- } \\
\text { buotojai }\end{array}$ & 54 & 26,0 & 70 & $33,7 *$ & 48 & 23,1 & 26 & 12,5 & 10 & 4,8 & \\
\hline
\end{tabular}


buvo suskirstyti i 4 blokus: socialiniai aplinkos veiksniai, gyvenimo įvykiai ir pokyčiai, darbo įvykiai ir pokyčiai, asmeniniai îvykiai ir individualių charakteristikų pokyčiai (3-6 lentelès).

Sveikatos veiksniai (arba stresoriai) retai veikia atskirai vienas nuo kito, dažniau veikia keli vienu metu, skatindami vienas kitą. Pavyzdžiui, skyrybos gali paskatinti žalingų ipročių toleravimą, sukelti miego sutrikimus, ittampą darbe ir pan. Socialiniai veiksniai (stresoriai) gali būti ir pozityvūs (įstojimas ị mokyklas ir jų baigimas, vedybos), ir neigiami ivvykiai, sukeliantys žmogui ir jo sveikatai pozityvų poveikị. Vienas jų - darbas, darbo vietos pokyčiai, kurie, anot V.
Janušonio (2008), yra tarsi tam tikra prievarta, tačiau žmogus ịprasmina savo gyvenimą galèdamas dirbti ir užsidirbti, parodydamas ne tik kitiems, bet ir sau pačiam, kad gali būti naudingas. Mylimas, mėgstamas darbas padeda žmogui isitvirtinti socialinejje grupejje. Negatyvių įvykių sukeltas stresas gali padaryti pozityvų poveiki individui ir jo sveikatai. Socialinis stresas yra šiuolaikinès ,rizikos visuomenès“ bruožas [10].

Per 50 proc. žmogaus sveikatos priklauso nuo jo gyvensenos. Didelę įtaką ligų atsiradimui turi netinkama mityba, per mažas fizinis aktyvumas, nesaikingas alkoholio vartojimas ar rūkymas. Pastarasis yra vienas didžiausių sveikatos

5 lentelè. Darbo vietos pokyčiai, jų svarba sveikatai ir sveikatos priežiūrai.

\begin{tabular}{|c|c|c|c|c|c|c|c|c|c|c|c|c|}
\hline \multirow{3}{*}{$\begin{array}{l}\text { Pasirinkimo vari- } \\
\text { antai }\end{array}$} & \multirow{3}{*}{ Respondentai } & \multicolumn{10}{|c|}{ Vertinimas } & \multirow{3}{*}{ 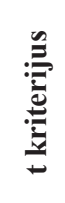 } \\
\hline & & \multicolumn{2}{|c|}{ labai svarbūs } & \multicolumn{2}{|c|}{ svarbūs } & \multicolumn{2}{|c|}{$\begin{array}{l}\text { vidutinès } \\
\text { svarbos }\end{array}$} & \multicolumn{2}{|c|}{$\begin{array}{c}\text { nelabai svar- } \\
\text { būs }\end{array}$} & \multicolumn{2}{|c|}{ nesvarbūs } & \\
\hline & & $\mathrm{N}$ & proc. & $\mathrm{N}$ & proc. & $\mathrm{N}$ & proc. & $\mathrm{N}$ & proc. & $\mathrm{N}$ & proc. & \\
\hline \multirow{2}{*}{$\begin{array}{l}\text { Darbo vietos po- } \\
\text { kyčiai }\end{array}$} & Pacientai & 61 & 27,7 & 83 & $37,7 *$ & 44 & 20,0 & 26 & 11,8 & 6 & 2,7 & \multirow[b]{2}{*}{1,07} \\
\hline & $\begin{array}{l}\text { Medicinos } \\
\text { darbuotojai }\end{array}$ & 48 & 23,1 & 88 & $42,3 * * *$ & 46 & 22,1 & 19 & 9,1 & 7 & 3,4 & \\
\hline \multirow[t]{2}{*}{ Nedarbas } & Pacientai & 119 & $54,1 * * *$ & 76 & 34,5 & 19 & 8,6 & 5 & 2,3 & 1 & 0,5 & \multirow[b]{2}{*}{0,78} \\
\hline & $\begin{array}{l}\text { Medicinos } \\
\text { darbuotojai }\end{array}$ & 133 & $63,9 * * *$ & 50 & 24,0 & 14 & 6,7 & 2 & 1,0 & 9 & 4,3 & \\
\hline \multirow{2}{*}{$\begin{array}{l}\text { Profesinès hierar- } \\
\text { chijos pokyčiai }\end{array}$} & Pacientai & 51 & 23,2 & 84 & $38,2 *$ & 47 & 21,4 & 27 & 12,3 & 11 & 5,0 & \multirow[b]{2}{*}{1,12} \\
\hline & $\begin{array}{l}\text { Medicinos } \\
\text { darbuotojai }\end{array}$ & 40 & 19,2 & 80 & $38,5 * * *$ & 54 & 26,0 & 30 & 14,4 & 4 & 1,9 & \\
\hline \multirow{2}{*}{$\begin{array}{l}\text { Nesutarimai darbe } \\
\text { (su darbo draugais, } \\
\text { viršininkais) }\end{array}$} & Pacientai & 84 & $38,2 * * *$ & 78 & 35,5 & 35 & 15,9 & 18 & 8,2 & 5 & 2,3 & \multirow[b]{2}{*}{1,04} \\
\hline & $\begin{array}{l}\text { Medicinos } \\
\text { darbuotojai }\end{array}$ & 45 & 21,6 & 85 & $40,9 * * *$ & 49 & 23,6 & 21 & 10,1 & 8 & 3,8 & \\
\hline \multirow[t]{2}{*}{ Karjeros sunkumai } & Pacientai & 65 & 29,5 & 84 & $38,2 *$ & 44 & 20,0 & 20 & 9,1 & 7 & 3,2 & \multirow[b]{2}{*}{1,06} \\
\hline & $\begin{array}{l}\text { Medicinos } \\
\text { darbuotojai }\end{array}$ & 45 & 21,6 & 85 & $40,9 * * *$ & 49 & 23,6 & 21 & 10,1 & 8 & 3,8 & \\
\hline \multirow[t]{2}{*}{ Nesėkmės darbe } & Pacientai & 86 & 39,1 & 91 & $41,4 * * *$ & 27 & 12,3 & 13 & 5,9 & 3 & 1,4 & \multirow[b]{2}{*}{0,93} \\
\hline & $\begin{array}{l}\text { Medicinos } \\
\text { darbuotojai }\end{array}$ & 94 & $44,2 * * *$ & 74 & 35,6 & 29 & 13,9 & 8 & 3,8 & 5 & 2,4 & \\
\hline \multirow{2}{*}{$\begin{array}{l}\text { Bloga darbo } \\
\text { aplinka, sąlygos, } \\
\text { ịrankiai }\end{array}$} & Pacientai & 96 & $43,6 * * *$ & 93 & 42,3 & 19 & 8,6 & 11 & 5,0 & 1 & 0,5 & \multirow{2}{*}{0,84} \\
\hline & $\begin{array}{l}\text { Medicinos } \\
\text { darbuotojai }\end{array}$ & 116 & $55,8 * * *$ & 61 & 29,8 & 20 & 9,6 & 8 & 3,8 & 3 & 1,4 & \\
\hline \multirow[t]{2}{*}{ Itemptas darbas } & Pacientai & 112 & $50,9 *$ & 81 & 36,8 & 19 & 8,6 & 5 & 2,3 & 3 & 1,4 & \multirow[b]{2}{*}{0,84} \\
\hline & $\begin{array}{l}\text { Medicinos } \\
\text { darbuotojai }\end{array}$ & 135 & $64,9 * * *$ & 53 & 25,5 & 12 & 5,8 & 6 & 2,9 & 2 & 1,0 & \\
\hline \multirow{2}{*}{$\begin{array}{l}\text { Kenksmingos darbo } \\
\text { sąlygos }\end{array}$} & Pacientai & 139 & $63,2 * * *$ & 62 & 28,2 & 11 & 5,0 & 6 & 2,7 & 2 & 0,9 & \multirow[b]{2}{*}{0,79} \\
\hline & $\begin{array}{l}\text { Medicinos } \\
\text { darbuotojai }\end{array}$ & 134 & $64,4 * * *$ & 54 & 26,0 & 17 & 8,1 & 3 & 1,4 & 0 & 0,0 & \\
\hline \multirow[t]{2}{*}{ Išèjimas ị pensiją } & Pacientai & 54 & 24,5 & 64 & 29,1 & 40 & 18,2 & 43 & 19,5 & 19 & 8,6 & \multirow[b]{2}{*}{1,28} \\
\hline & $\begin{array}{l}\text { Medicinos } \\
\text { darbuotojai }\end{array}$ & 36 & 17,3 & 81 & $38,9 * * *$ & 51 & 24,5 & 32 & 15,4 & 8 & 3,8 & \\
\hline
\end{tabular}


rizikos veiksnių, kurių galima išvengti [4]. Bendriems sveikatos rodikliams įtakos turi ir kintančios gyventojų sudèties rodikliai. Ypač didelis dėmesys skiriamas senyvo amžiaus žmonèms, kurių per pastaruosius 30 metų padidejjo net 2-3 kartus [7].

Remiantis 3 lenteleje pateiktais duomenimis galima teigti, kad tarp pacientų yra daugiausia manančių, jog nedarbas, skurdas (nepakankamos pajamos), profesine diskriminacija labiausiai veikiantys sveikatą socialinès aplinkos veiksniai. Medicinos medicinos darbuotojai iš dalies pritare pacientų nuomonei, jie profesinę diskriminaciją įvertino kaip svarbų veiksnị.

Iš pateiktų gyvenimo įvykių ir pokyčiu veiksnių sąrašo, pacientai kaip „labai svarbius" nurode šiuos veiksnius: artimujų mirtis ir ligos, skyrybos ar vedybos, nesutarimai šeimoje ir materialiniai (finansiniai) sunkumai bei skolos. Medicinos darbuotojai kaip „labai svarbius“ ar „svarbius“ gyvenimo ịvykius, kurie gali turèti įtakos sveikatai, nurodè artimujų mirtis ir ligas, skyrybas ar vedybas, nesutarimus šeimoje, materialinius sunkumus, gyvenimo vietos pakeitimą (32,2 proc.), naujų šeimos narių atsiradimą ir socialinę izoliaciją.

Tyrimo rezultatai atskleide, kad pacientai iš pateiktų darbo įvykių ir pokyčių veiksnių sąrašo kaip „labai svarbius" nurode šiuos veiksnius: nedarbas, nesutarimai darbe, nesèkmès darbe, bloga darbo aplinka bei sąlygos, ittemptas darbas ir kenksmingos darbo sąlygos. Medicinos darbuotojų atsakymai pasiskirste panašiai.

Medicinos personalas, kaip ir pacientai, iš pateiktų asmeninių îvykių ir individualių charakteristikų sąrašo išskyrè

6 lentelè. Asmeniniai įvykiai ir individualių charakteristikų pokyčiai, jų svarba sveikatai ir sveikatos priežiūrai.

\begin{tabular}{|c|c|c|c|c|c|c|c|c|c|c|c|c|}
\hline \multirow{3}{*}{$\begin{array}{l}\text { Pasirinkimo vari- } \\
\text { antai }\end{array}$} & \multirow{3}{*}{ Respondentai } & \multicolumn{10}{|c|}{ Vertinimas } & \multirow{3}{*}{ : } \\
\hline & & \multicolumn{2}{|c|}{ labai svarbūs } & \multicolumn{2}{|c|}{ svarbūs } & \multicolumn{2}{|c|}{$\begin{array}{l}\text { vidutinès } \\
\text { svarbos }\end{array}$} & \multicolumn{2}{|c|}{$\begin{array}{c}\text { nelabai svar- } \\
\text { būs }\end{array}$} & \multicolumn{2}{|c|}{ nesvarbūs } & \\
\hline & & $\mathrm{N}$ & proc. & $\mathrm{N}$ & proc. & $\mathrm{N}$ & proc. & $\mathrm{N}$ & proc. & $\mathrm{N}$ & proc. & \\
\hline \multirow{2}{*}{$\begin{array}{l}\text { Asmeninès sveikatos } \\
\text { sutrikimai }\end{array}$} & Pacientai & 133 & $60,5 * * *$ & 73 & 33,2 & 11 & 5,0 & 3 & 1,4 & 0 & 0,0 & \multirow[b]{2}{*}{0,66} \\
\hline & $\begin{array}{l}\text { Medicinos } \\
\text { darbuotojai }\end{array}$ & 143 & $68,8 * * *$ & 47 & 22,6 & 5 & 2,4 & 1 & 0,5 & 0 & 0,0 & \\
\hline \multirow[t]{2}{*}{ Žalingi ịpročiai } & Pacientai & 118 & $53,6 * * *$ & 76 & 34,5 & 20 & 9,1 & 5 & 2,3 & 1 & 0,5 & \multirow[b]{2}{*}{0,78} \\
\hline & $\begin{array}{l}\text { Medicinos } \\
\text { darbuotojai }\end{array}$ & 97 & $46,6 * *$ & 66 & 31,7 & 27 & 13,0 & 14 & 6,7 & 4 & 1,9 & \\
\hline \multirow[t]{2}{*}{ Miego sutrikimai } & Pacientai & 97 & $44,1 * * *$ & 95 & 43,2 & 25 & 11,4 & 3 & 1,4 & 0 & 0,0 & \multirow[b]{2}{*}{0,72} \\
\hline & $\begin{array}{l}\text { Medicinos } \\
\text { darbuotojai }\end{array}$ & 97 & $46,6 * * *$ & 82 & 39,4 & 20 & 9,6 & 6 & 2,9 & 3 & 1,4 & \\
\hline \multirow{2}{*}{$\begin{array}{l}\text { Nesėkmės moksle, } \\
\text { studijose }\end{array}$} & Pacientai & 65 & 29,5 & 89 & $40,5^{*}$ & 49 & 22,3 & 11 & 5,0 & 6 & 2,7 & \multirow[b]{2}{*}{0,98} \\
\hline & $\begin{array}{l}\text { Medicinos } \\
\text { darbuotojai }\end{array}$ & 63 & 30,0 & 72 & $34,6 *$ & 52 & 25,0 & 14 & 6,7 & 7 & 3,4 & \\
\hline \multirow{2}{*}{$\begin{array}{l}\text { Įstojimas ị mokyklas } \\
\text { ir jų baigimas }\end{array}$} & Pacientai & 57 & 25,9 & 70 & 31,8 & 50 & 22,7 & 31 & 14,1 & 12 & 5,5 & \multirow[b]{2}{*}{1,17} \\
\hline & $\begin{array}{l}\text { Medicinos } \\
\text { darbuotojai }\end{array}$ & 39 & 18,8 & 66 & 31,7 & 56 & 26,9 & 35 & 16,8 & 12 & 5,8 & \\
\hline \multirow{2}{*}{$\begin{array}{l}\text { Seksualiniai sutri- } \\
\text { kimai }\end{array}$} & Pacientai & 56 & 25,5 & 78 & $35,5^{*}$ & 44 & 20,0 & 33 & 15,0 & 9 & 4,1 & \multirow[b]{2}{*}{1,14} \\
\hline & $\begin{array}{l}\text { Medicinos } \\
\text { darbuotojai }\end{array}$ & 40 & 19,2 & 66 & 31,7 & 60 & 28,8 & 35 & 16,8 & 7 & 3,4 & \\
\hline \multirow[t]{2}{*}{ Nėštumas, abortas } & Pacientai & 77 & $35,0 * * *$ & 75 & 34,1 & 35 & 15,9 & 25 & 11,4 & 8 & 3,6 & \multirow[b]{2}{*}{1,13} \\
\hline & $\begin{array}{l}\text { Medicinos } \\
\text { darbuotojai }\end{array}$ & 63 & $30,3 *$ & 61 & 29,3 & 40 & 19,2 & 33 & 15,9 & 11 & 5,3 & \\
\hline \multirow[t]{2}{*}{ Nelaisvė } & Pacientai & 91 & $41,4 * * *$ & 75 & 34,1 & 24 & 10,9 & 20 & 9,1 & 10 & 4,5 & \multirow[b]{2}{*}{1,14} \\
\hline & $\begin{array}{l}\text { Medicinos } \\
\text { darbuotojai }\end{array}$ & 83 & $39,9 *$ & 60 & 28,8 & 23 & 11,1 & 28 & 13,5 & 14 & 6,7 & \\
\hline \multirow{2}{*}{$\begin{array}{l}\text { Tarnyba kariuome- } \\
\text { nëje }\end{array}$} & Pacientai & 47 & 21,4 & 70 & $31,8^{*}$ & 50 & 22,7 & 35 & 15,9 & 18 & 8,2 & \multirow[b]{2}{*}{1,22} \\
\hline & $\begin{array}{l}\text { Medicinos } \\
\text { darbuotojai }\end{array}$ & 29 & 13,9 & 62 & 29,8 & 45 & 21,6 & 42 & 20,2 & 30 & 14,4 & \\
\hline
\end{tabular}


šiuos „labai svarbius“ veiksnius: asmeninès sveikatos sutrikimai, miego sutrikimai, žalingi ịpročiai, něštumas ar abortas, nelaisvè. Papildomai kaip svarbius, pacientai įvardijo: tarnyba kariuomenejje, seksualiniai sutrikimai ir nesékmès moksle ar studijose.

Apklausti medicinos darbuotojai mano, jog analizuojami socialiniai veiksniai turi itakos pacientui ir jo sveikatai. Statistiškai reikšmingai $(\mathrm{p}<0,001)$ daugiau kaip pusė apklaustujų nurodè, jog socialiniai veiksniai riboja kasdienę veiklą $(85,1$ proc.), bendravimą ( 80,3 proc.), paveikia dienotvarkę ( 79,3 proc.), riboja sveikatos priežiūrą ir pagrindinių poreikių tenkinimą (75,5 proc.), priverčia keisti spartų gyvenimo būdą ( 76,9 proc.) ir padidina atskirties (vienišumo) riziką ( 71,2 proc.).

Apklaustų pacientų nuomone, socialiniai veiksniai riboja kasdienę veiklą ( 63,2 proc.), paveikia dienotvarkę (63,2 proc.), riboja sveikatos priežiūrą ( 52,7 proc.), riboja pagrindinių poreikių tenkinimą ( 52,7 proc.) bei priverčia keisti spartų gyvenimo būdą (62,7 proc.).

Siekiant išsiaiškinti, ar tam tikrų gyventojų grupių sveikatos priežiūros prieinamumas priklauso nuo socialinių veiksnių ịtakos, respondentai buvo prašomi ịvertinti tam tikrų socialinių gyventojų grupių prieinamumą (7 lentelè).

Apklausti pacientai statistiškai reikšmingai nurodè, jog socialiniai veiksniai gali mažinti sveikatos priežiūros prieinamumą nedirbantiems (49,5 proc.), turintiems mažas pajamas (56,8 proc.), senyvo amžiaus ( 40,0 proc.) ir priklausomybę turintiems asmenims (42,3 proc.). Apklaustų medicinos darbuotojų nuomoné sutapo su pacientų nuomone. Apklausti medicinos darbuotojai statistiškai reikšmingai nurodè, jog socialiniai veiksniai gali mažinti sveikatos priežiūros prieina-

7 lentelè. Socialinių veiksnių ịtaka tam tikrų gyventojų grupių sveikatos priežiūros prieinamumui. Respondentu (pacientu) nuomoné.

\begin{tabular}{|c|c|c|c|c|c|c|c|c|}
\hline \multirow{3}{*}{$\begin{array}{l}\text { Gyventojų } \\
\text { grupės }\end{array}$} & \multicolumn{8}{|c|}{ Vertinimas (pacientų nuomonè) } \\
\hline & \multicolumn{2}{|c|}{$\begin{array}{l}\text { toks pat kaip } \\
\text { visų }\end{array}$} & \multicolumn{2}{|c|}{ blogesnis } & \multicolumn{2}{|c|}{ geresnis } & \multicolumn{2}{|c|}{ nežinau } \\
\hline & $\mathrm{N}$ & proc. & $\mathrm{N}$ & proc. & $\mathrm{N}$ & proc. & $\mathrm{N}$ & proc. \\
\hline Nedirbantys & 86 & 39,1 & 109 & $49,5 *$ & 4 & 1,8 & 21 & 9,5 \\
\hline $\begin{array}{l}\text { Turintys mažas } \\
\text { pajamas }\end{array}$ & 75 & 34,1 & 125 & $56,8 * * *$ & 2 & 0,9 & 18 & 8,2 \\
\hline Vieniši & 123 & $55,9 * * *$ & 58 & 26,4 & 7 & 3,2 & 32 & 14,5 \\
\hline Seni žmonès & 99 & $45,0 * * *$ & 88 & 40,0 & 8 & 3,6 & 25 & 11,4 \\
\hline $\begin{array}{l}\text { Priklausomybę } \\
\text { turintys } \\
\text { asmenys }\end{array}$ & 61 & 27,7 & 93 & $42,3 *$ & 9 & 4,1 & 57 & 25,9 \\
\hline $\begin{array}{l}\text { Seksualinès } \\
\text { mažumos }\end{array}$ & 92 & $41,8 * * *$ & 42 & 19,1 & 6 & 2,7 & 80 & 36,4 \\
\hline $\begin{array}{l}\text { Daugiavaikès } \\
\text { Šeimos }\end{array}$ & 126 & $57,2 * * *$ & 45 & 20,5 & 9 & 4,1 & 40 & 18,2 \\
\hline
\end{tabular}

mumą nedirbantiems ( 62,0 proc.), turintiems mažas pajamas (63,9 proc.), senyvo amžiaus ( 48,6 proc.) ir priklausomybę turintiems asmenims ( 49,0 proc.).

Pastebimas neturtas (gaunamos mažesnès pajamos), menkesnis išsimokslinimas, sudètingas visuomeninių tarnybų prieinamumas, blogesnis sveikatos priežiūros prieinamumas ypač tarp kaimo gyventojų, todèl labai nukenčia jų sveikata [13].

Remiantis PSO, kiekvienas pacientas turi gauti tokias sveikatos priežiūros paslaugas, kurios užtikrintų optimaliausius sveikatos gerinimo rezultatus, atsižvelgiant ị mokslo pasiekimus, paciento amžių, ligos diagnozę, reakcijas ị gydymą ir kt. Rezultatų turi būti siekiama minimaliai naudojant ribotas priemones, kuo labiau sumažinti traumų, nepageidaujamų reiškinių ir komplikacijų riziką [30].

Statistiškai reikšmingai medicinos darbuotojai išsakè nuomonę apie sveikatos priežiūros ir socialinių veiksnių gerinimą. 59,1 proc. medicinos darbuotojų mano, jog turètų būti tenkinami visų socialinių grupių pacientų socialiniai poreikiai, teikiant aukščiausios kokybès sveikatos priežiūros paslaugas. 44,2 proc. medicinos darbuotojų mano, jog tik gerinant asmens sveikatos priežiūros kokybę galima užtikrinti tinkamą sveikatos priežiūrą, veikiamą socialinių veiksnių. Kiti sveikatos specialistai (31,3 proc.) teigè, jog tinkamos, savalaikès ir reikiamos informacijos apie sveikatos priežiūros ir socialines paslaugas teikimas pacientui gali pagerinti sveikatos priežiūrą. Vienas iš apklaustų medicinos specialistų atsakymų eilutėje „kita“ nurodè, jog materiali gerovė pagerintų asmens sveikatos priežiūros kokybę ir, žinoma, jai turinčius įtakos socialinius veiksnius.

Sveikatos priežiūros įstaigoje turi funkcionuoti profesionalioji kokybè, apimanti kvalifikuotą sveikatos paslaugų, atitinkančiu teisètas pacientų reikmes, teikimą pagal ịstaigoje patvirtintus sveikatos priežiūros paslaugu teikimo standartus (procedūras), ir valdymo kokybé -efektyviausias ir produktyviausias išteklių panaudojimas, laikantis vadovaujančiu įstaigų nurodymų ir LR įstatymų, kokybès vadybos sistemos funkcionavimas pagal ịstaigoje nustatytus prioritetus [27]. Atlikus tyrimą, statistiškai reikšmingai skirèsi $(p<0,05)$ medicinos darbuotojų nuomonè dèl priemonių, kuriomis jie gali prisidetti, siekiant pagerinti sveikatos priežiūrą. 64,4 proc. medicinos darbuotojų nurodè, jog teikdami savo pasiūlymus dèl inovatyvių gydymo priemonių, organizaciniu metodų taikymo bei teikiamų paslaugų kokybès gerinimo, jie gali prisidèti prie sveikatos priežiūros valdymo. 
Nemaža dalis medicinos darbuotojų (53,8 proc.) mano, kad aktyviai klausydamiesi pacientų pasakojimo, ieškodami ir pastebėdami tiek vidaus ligas, tiek emocinio streso simptomus, gali tiesiogiai prisidèti prie sveikatos priežiūros paslaugų gerinimo. Tai patvirtina ir kiti autoriai, teigiantys, kad pacientams svarbu ne tik tai, kaip organizuojama paslauga ir koordinuojama gydymo proceso eiga, bet ir emocinis bei psichosocialinis sveikatos priežiūros aspektai, nuo kurių taip pat priklauso gydymo bei slaugos rezultatas. Svarbu demesys, pagarba, konfidencialumas, privatumo išsaugojimas, empatija, bendravimas ir atvirumas [27,28]. Sveikatos priežiūros specialistai prisideda prie teigiamos paciento savijautos turima kompetencija, medicinos žiniomis ir savo asmeniniais bruožais - gebejjimu išklausyti, suprasti, nuraminti, bendrauti, kalbetis apie pacientui svarbius dalykus [14].

Tvaraus sveikatos apsaugos sistemos organizacijos vystymosi garantija - įrodymais pagrịstas valdymas. Tai daug sudètingesnis, turintis glaudžias sąsajas su medicina ir sveikata, reikalaujantis daugiau atsakomybės ir kūrybiškumo nei tradiciniais principais pagristas valdymas $[18,20]$. Sveikatos apsaugos sistemos organizacijos valdymas taip pat susijęs su organizacijos ir jos narių emociniu atsaku ị išorinès ir vidinès aplinkos darbo proceso poveikị. Analizuodami sveikatos priežiūros valdymo, vertinimo sritis, dažniausiai mokslininkai išskiria šiuos aspektus: teikiamų paslaugų prieinamumą, saugą, informacijos suteikimą, sveikatos priežiūros specialistų profesinį pasirengimą [24].

D. Bubnienė ir J. Ruževičius (2010), aptardami pagrindinius sveikatos priežiūros vadybos aspektus, teigia, kad saugios ir aukštos kokybės pacientų priežiūros pagrindas - komandinis darbas, medicinos personalo vidinè komunikacija bei komunikavimas su pacientais [3].

Lyginant rezultatus pagal sveikatos priežiūros specialistu darbo grupes ir jų nuomonę dèl priemonių, kuriomis medicinos darbuotojai galètų prisidèti prie pacientų sveikatos priežiūros gerinimo, galima pabrèžti, jog didesnè gydytojų dalis $(52,5$ proc.) mano, kad jie, prisidedami prie inovatyviu ir tvarių sveikatos sistemų formavimo, galètų pagerinti pacientų sveikatos priežiūros valdymą. Gydytojai (67,5 proc.), slaugytojos (64,0 proc.) ir kitas personalas $(62,1$ proc.) pritarè nuomonei, jog teikdami savo pasiūlymus sveikatos priežiūros įstaigų administracijoms dẻl inovatyvių gydymo priemonių taikymo, teikiamų paslaugų kokybès gerinimo, organizacinių metodų taikymo, galètų pagerinti sveikatos priežiūros paslaugų kokybę.

Daugiau nei pusè visų darbo grupių atstovų pritarè, jog i̊siklausymas i paciento nusiskundimus ir visapusis dèmesys sveikatai sudaro sąlygas gerinti paslaugų kokybę.

Medicinos darbuotojai savo vadybinius ịūdžius, kurie geriausiai prisideda prie sveikatos priežiūros gerinimo, kaip labai gerus nurodè bendravimo ịgūdžius (49,0 proc.). Kaip gerai išvystytus, sveikatos specialistai reikšmingai $(\mathrm{p}<0,001)$ išskyrè analizavimo ( 49,0 proc.), sugebejjimo ịtikinti $(48,1$ proc.) ir planavimo (51,4 proc.) ịūdžius.

\section{Išvados}

1. Išskirti sveikatos priežiūrą labiausiai veikiantys socialiniai veiksniai: socialinès aplinkos veiksniai (nedarbas, skurdas, profesinè diskriminacija); gyvenimo įvykiai (artimujų mirtys ir ligos, skyrybos ir vedybos, ilgalaikiai sutuoktiniu išsiskyrimai, nesutarimai šeimoje bei materialiniai sunkumai ir skolos); darbo įvykiai ir pokyčiai (nedarbas, nesutarimai darbe, nesèkmès darbe, bloga darbo aplinka bei sąlygos, itemptas darbas, kenksmingos darbo sąlygos).

2. Tiek pacientai, tiek medicinos darbuotojai skirtingai vertina grupių, skatinančių socialinių veiksnių itaką sveikatos priežiūrai, svarbą. nurodo, jog jiems pasirenkant sveikatos priežiūros įstaigą, didžiausią ịtaką turi draugai bei kiti artimieji. Daugiau nei pusė apklaustų medicinos darbuotojų mano, jog pacientų draugijos, socialiniai tinklai internete, savitarpio paramos grupès, draugai bei artimieji yra tos subjektų grupès, kurios daro didžiausią ịtaką socialiniams veiksniams, veikiantiems sveikatos priežiūrą.

3. Siekiant pagerinti sveikatos priežiūros paslaugas, medicinos darbuotojų nuomone, turètų būti tenkinami visų socialinių grupių pacientų socialiniai poreikiai, teikiant aukščiausios kokybės sveikatos priežiūros paslaugas. Medicinos darbuotojai, teikdami savo pasiūlymus dèl inovatyvių gydymo priemonių, organizacinių metodų taikymo bei teikiamų paslaugų kokybės gerinimo, gali prisidèti prie sveikatos priežiūros valdymo.

\section{Literatūra}

1. Asworth R, Ferlie E, Hammerschmid G. et al. Theorizing contemporary public management: international and comparative perspectives. British Journal of Management 2013;24:s1-s17. https://doi.org/10.1111/1467-8551.12035

2. Berger PL. Sociologija. Vilnius: Litterae Universitatis, 1995.

3. Bubnienè D., Rudževičius J. Kokybès valdymo sveikatos priežiūros institucijoje ypatumai. Verslo ir teisés aktualijos, 2010;5:22-40.

https://doi.org/10.5200/1822-9530.2010.01

4. Buivydas R., Černiauskas G., Černiauskas N. ir kt. Lietuvos sveikatos sektorius amžių sandūroje. Vilnius: Sveikatos ekonomikos centras, 2010.

5. Danusevičienẻ L., Jurkuvienė R. Požiūrio ị pacientą intensyviosios terapijos skyriuje transformacijos savitumai. Medicina, 2010;46 (1):8-15.

6. Grondahl VA, Kirchhoff JW, Andersen KL, et al. Health care quality from patients' perspective: a comparative study between an old and a new, high-tech hospital. Journal Multidisciplinary 
Healthcare 2018;11:591-600.

https://doi.org/10.2147/JMDH.S176630

7. Jankauskienė D., Pečiūra, R. Sveikatos politika ir valdymas. Vilnius: Mykolo Romerio universitetas, 2007.

8. Janušonis V. Sveikatos priežiūros kokybès ir tinkamumo pokyčiai karantino dèl COVID-19 epidemijos metu: pacientu nuomonè ir vertinimas (atvejo analizè). Sveikatos mokslai, 2020; 30(7):72-79.

https://doi.org/10.35988/sm-hs.2020.181

9. Janušonis V. Organizacinè elgsena ir kokybė sveikatos priežiūroje. Klaipėda: S. Jokužio leidykla-spaustuvė, 2017.

10. Janušonis V. Sveikata ir valdoma sveikatos priežiūra. Klaipėda: S. Jokužio leidykla-spaustuvè, 2008.

11. Jurgelenas A., Mačiūnas E., Juozulynas A. ir kt. Sveikatos socialinè plètra. Vilnius: Naujoji matrica, 2007.

12. Juškelienė V. Visuomenès sveikatos ịvadas: sveikatos samprata, sveikatos rizikos ir palaikantys veiksniai. Vilnius: Vilniaus pedagoginio universiteto leidykla, 2007.

13. Kondrašovienė L., Kupriūnienė Z.J. Socialinis darbas ir sveikatos priežiūra. Kaunas: Kauno medicinos universitetas, 2008.

14. Leonavičius V., Baltrušaitytė G., Naujokaitė I. Sociologija ir sveikatos priežiūros paslaugų vartotojas. Kaunas: Vytauto Didžiojo universitetas, 2007.

15. Leslie HH, Sun Z, Kruk ME. Association between infrastructure and observed quality of care in 4 healthcare services: A crosssectional study of 4,300 facilities in 8 countries. PLoS Med 2017;14(12):e1002464 https://doi.org/10.1371/journal.pmed.1002464

16. Lietuvos Respublikos pacientų teisių ir žalos sveikatai atlyginimo įstatymas I-1562. 2009. Valstybès žinios, Nr. 115-4284.

17. Mikaliūkštienė A., Baltokaitė L., Kalibatienė D., Jerdiakova N. Sveikatos priežiūros paslaugų kokybès vertinimas kardiologijos centre: pacientų požiūris.Visuomenès sveikata, 2018;28(5): $32-40$. https://doi.org/10.5200/sm-hs.2018.056

18. Moskowitz D, Bodenheimer T. Moving from evidence-based medicine to evidence-based heath. J Gen Intern Med 2011;26(6):658-660. https://doi.org/10.1007/s11606-010-1606-4

19. Nylenna M, Bjertnaes O, Saunes IS, Lindahl AK. What is Good Quality of Health Care? Professions and Professionalism 2015;5(1):1893-1049. https://doi.org/10.7577/pp.909

20. Patrician PA, Loan L, McCarthly M, et al. Towards Evidence-based Management: creating an Informative dabase of nursing-sensitive indicators. Journal of Sursing scholarship 2010; 42:358-366. https://doi.org/10.1111/j.1547-5069.2010.01364.x

21. Pekacz A, Kadalska E, Skoczylas A, Targowski T. Patient satisfaction as an element of health care quality - a single-center Polish survey. Rheumatology 2019;57:135-144. https://doi.org/10.5114/reum.2019.86423

22. Pomey MP, Ghadiri DP, Karazivan P. Patients as partners: a qualitative study of patients' engagement in their health care.
PLoS ONE 2015;10(4):eo122499.

https://doi.org/10.1371/journal.pone.0122499

23. Pukėnas K. Kokybinių duomenų analizė SPSS programa. Kaunas: Lietuvos kūno kultūros akademija, 2011.

24. Quality Assurance. Health - EU. http://ec.europa.eu/health-u/ care for me/quality asurance/

25. Simonet D. Assessment of new public management in health care: the French case. Health Research Policy and Systems 2014; 12:57-67.

https://doi.org/10.1186/1478-4505-12-57

26. Simonet D. The new public management theory and European health care reforms. Canadian Public Administration 2008;51:617-635. https://doi.org/10.1111/j.1754-7121.2008.00044.x

27. Šilys A. Asmens sveikatos priežiūros įstaigų veiklos kokybès valdymas. Vilnius, 2013.

28. Štaras K., Vedlūga T., Kalvelytè N. Sveikatos priežiūros įstaigų paslaugų kokybès prieinamumo ir priimtinumo vertinimas ir analizè. Sveikatos mokslai, 2013;23(4):27-33. https://doi.org/10.5200/sm-hs.2013.088

29. World Health Organisation. Social determinants of health. https://www.who.int/health-topics/social-determinants-ofhealth\#tab=tab_1

30. World Health Organisation. Health is a fundamental human right. Statement by Dr Tedros Adhanom Ghebreyesus (WHO Director-General), 2017. http://www.who.int/mediacentre/ news/statements/fundamental-human-right/en/

\section{MANAGEMENT OF HEALTH CARE AND SOCIAL FACTORS INTERFACES OF THE PATIENTS J. Platakytè}

Keywords: health, health care, patient, social factors, management.

Summary

The article introduces the health care and social factors and their interfaces of the patients treated at hospitals as well as the management of health care and social factors interfaces. In order to estimate the interfaces of health care and social factors as well as the management of the interfaces of social factors and health care has been assessed performing the quantitative analysis with the original questionnaire compiled by the author.

The empirical results of the study show that the groups of the social factors affecting the patients ' health are the following: the factors of social environment, work events and changes, personal events and changes in individual characteristics, life events and changes and others. Unemployment, poverty, material (financial) difficulties and debts, bad work environment and conditions, busy job, harmful work conditions, illnesses and deaths the people that are close - are the factors influencing the health care the most. Suggestions made by medical staff regarding the application of inovative means and organisational methods as well as the improvement of the quality of the services can contribute to the management of health care.

Correspondence to: j.platakyte@kul.lt

Gauta 2021-10-18 